DOI: 10.19195/0137-1150.163.15

\author{
AURELIA KOTKIEWICZ \\ Uniwersytet Pedagogiczny w Krakowie, Polska \\ akotkiewicz@op.pl
}

\title{
„Wstrzymaj się chwilo! Ty jesteś tak piękną!"1 Motyw Fausta w literaturze rosyjskiej lat dwudziestych i trzydziestych XX wieku
}

Faust, szesnastowieczny niemiecki alchemik i mag, stawiany obok takich postaci, jak Prometeusz czy Lucyfer, jest uosobieniem istoty nieśmiertelnej, wolnej i niezależnej, wiecznie nienasyconej. W perspektywie ponadczasowej dzieje doktora Fausta, buntownika pragnącego pokonać czas i śmierć, owładniętego ideą przekroczenia wszelkich granic $\mathrm{w}$ imię absolutnego poznania, nie tyle uosabiają dramat człowieka, ile przywołują prometejski mit kreacji.

Motyw Fausta, jeden z najważniejszych w literaturze i sztuce europejskiej, jest także obecny w twórczości rosyjskich klasyków, by wspomnieć Wasilija Żukowskiego $^{2}$, Aleksandra Puszkina ${ }^{3}$ czy Iwana Turgieniewa ${ }^{4}$, a także w literaturze rosyjskiej Srebrnego Wieku, eksponującej problematykę metafizyczną. Wątek Faustowskiego sporu z Bogiem i ze światem oraz pragnienie osiągnięcia doskonałości - wszystko to wpisuje się w filozoficzne, religijne i artystyczne koncepcje symbolizmu, nawołujące do przekraczania granic realności w imię Absolutu. Na takie odczytanie dramatu o Fauście w sposób istotny wpłynęła filozofia Friedricha Nietzschego z jego ideą „woli mocy” i „przewartościowania wszystkich

1 J.W. Goethe, Faust, tłum. J. Paszkowski, Kraków 2002, s. 65.

${ }^{2}$ Wasilij Żukowski był jednym z pierwszych poetów rosyjskich, który przybliżył czytelnikowi twórczość niemieckiego pisarza.

${ }^{3}$ W wierszu Puszkina Scena z Fausta (Сиена из Фауста, 1825) tytułowy Faust uosabia dziewiętnastowieczny typ rosyjskiego „zbędnego człowieka”, melancholika głęboko rozczarowanego życiem. Należy podkreślić, że w kręgu romantyków rosyjskich twórczość Goethego, rozpatrywana w duchu filozofii Friedricha Schellinga cieszyła się ogromną popularnością.

${ }^{4}$ Motyw faustowski pojawia się w noweli filozoficznej Turgieniewa Faust (Фaycm, 1856), utrzymanej w nurcie pesymizmu spod znaku filozofii Arthura Schopenhauera. Jej tematem przewodnim jest tragizm losu ludzkiego. 
wartości”. W tym właśnie aspekcie może być interpretowana koncepcja „bogoczłowieczeństwa" Władimira Sołowjowa, której istotą jest integracja dwóch pierwiastków: boskiego i ludzkiego. Idea odnowy świata w interpretacji tego filozofa opierała się przede wszystkim na wewnętrznej przebudowie człowieka, w której rolę nadrzędną miała odegrać sztuka ${ }^{6}$.

Faustowska ekspresja indywidualizmu, upojenie mocą, wieczne nienasycenie to charakterystyczne cechy poezji symbolistów: Wiaczesława Iwanowa, Konstantina Balmonta, Andrieja Biełego czy Walerija Briusowa ${ }^{7}$, a także twórczości preekspresjonisty Leonida Andriejewa ${ }^{8}$. Wiara w człowieka obdarzonego boską potęgą tworzenia, który wzorem Fausta marzy o osiągnięciu nieśmiertelności, jest podstawą filozofii Nikołaja Fiodorowa. Odrzuca on śmierć jako fakt ostateczny, uznając, że jedynym sposobem jej pokonania jest powszechne zjednoczenie ludzi i wskrzeszenie zmarłych przodków, co uczyni człowieka nieśmiertelnym ${ }^{9}$.

Faustowski motyw wiecznej młodości i przekroczenia barier uniemożliwiających człowiekowi absolutne poznanie i panowanie nad światem jest obecny w idei „bogotwórstwa” Maksyma Gorkiego. Zachwyt nad nieograniczonymi możliwościami Człowiekoboga, który dzięki sile swojego rozumu jest w stanie podporządkować sobie przyrodę, wyrażony został przez pisarza w Pieśni o Zwiastunie Burzy (Песня о Буревестнике, 1901), Dzieciach słońca (Дети солниа, 1905) oraz poemacie Człowiek (Человек, 1903). W artykule O karamazowszczyźnіе (О карамазовщине, 1913) Gorki, propagując postawę aktywizmu, wystąpił przeciwko kultowi cierpienia i pokory oraz eksponowaniu przez literaturę rosyjską mroków ludzkiej duszy i roztrząsaniu przez nią problemów metafizycznych:

Перед нами - огромная работа внутренней реорганизации не только в социальнополитическом смысле, но и в психологическом. [...] Нам больше, чем кому-либо, необходимо духовное здоровье, бодрость, вера в творческие силы разума и воли ${ }^{10}$.

${ }^{5}$ O szczególnym wpływie filozofii Nietzschego na literaturę rosyjską zob. А. Эткинд, Эрос невозможного. История психоанализа в России, Санкт-Петербург 1993.

${ }^{6}$ Drogą wiodącą ku przekroczeniu granic ziemskich i osiągnięciu jedności z kosmosem miała się stać myśl antropozoficzna Rudolfa Steinera, którą fascynowało się wielu artystów rosyjskich, między innymi poeta Andriej Bieły, aktor Michaił Czechow oraz malarz Wassily Kandinsky.

${ }^{7}$ Interesujące odczytanie motywu Fausta przynosi powieść Ognisty aniol (Огненный ангел, 1907-1908). W warstwie światopoglądowej i poetyckiej utworu obraz Fausta symbolizuje pragnienie poznania istoty piękna za cenę różnorakich doświadczeń metafizycznych. Na uwagę zasługuje fakt, że Briusow jest jednym z tłumaczy Fausta Goethego na język rosyjski; pierwsza część dramatu niemieckiego twórcy w jego tłumaczeniu ukazała się drukiem w $1928 \mathrm{r}$.

${ }^{8}$ Te motywy widoczne są w dramacie Andriejewa Anatema (Анатэма, 1908) z mocno wyeksponowanym wątkiem Mefistofelesa oraz w powieści Dziennik Szatana (Дневник Cатаны, 1921).

${ }^{9}$ Dzisiaj, w dobie inżynierii genetycznej, filozoficzne poszukiwania Fiodorowa zdają się urzeczywistniać. Już w latach siedemdziesiątych XX wieku w Stanach Zjednoczonych opracowano metodę kriokonserwacji, czyli zabezpieczania od rozkładu ciał ludzi umierających, w nadziei na ich wskrzeszenie w przyszłości.

${ }^{10}$ М. Горький, О карамазовщъине, суt. za: А. Флакер, Предпосылки социиалистического реализма, „Вопросы литературы” 1992, nr 1, s. 68. 
Panaceum na wszelkie cierpienia ludzkie zdaniem pisarza miała się stać rewolucja społeczna oraz podporządkowanie jednostki interesom kolektywu. Te peany na cześć dumnego „,bohatera czynu” przybrały w Rosji formę utopii społecznej, a sam Gorki usankcjonował swoim autorytetem bolszewickie marzenie o „wyhodowaniu” nowego człowieka, kolektywnego homo novus ${ }^{11}$.

Motyw Fausta - buntownika i marzyciela — pojawia się również w publicystyce i twórczości artystycznej Anatolija Łunaczarskiego, pierwszego ministra oświaty w rządzie Lenina i współtwórcy koncepcji „bogoczłowieczeństwa”. W artykule pod znamiennym tytułem Rosyjski Faust (Русский Фаусm, 1902) w postaci uczonego-maga dostrzegł Łunaczarski pragnienie mocy, heroizm, tytaniczną siłę tworzenia i rozmachu:

Человек не удовлетворен, он страждет и творит идеалы, он идет вперед и, умирая, передает свои заветы детям и внукам, не ради оправдания мира и не в силу мучений совести, а потому, что в тяжелой борьбе за существование из него выработался творец и боец ${ }^{12}$.

Szczególny wyraz figura Fausta uzyskuje w dramacie misterium Łunaczarskiego Faust $i$ miasto (Фaycm u город, 1918) ${ }^{13}$. W przedmowie do utworu, bezpośrednio nawiązując do dzieła Goethego, Łunaczarski tak określił jego zamysł: „проблемы гения с его стремлением к просвещенному абсолютизму, с одной стороны, и демократии - с другой, - вот что волновало меня долго и звало к работе"14.

Faust jako nowy człowiek, rewolucjonista, marzący o nowym ziemskim ładzie, dąży do władzy absolutnej. Ofiara złożona w imię szczęścia ludzkości nie idzie na marne i nowy Faust, samozwańczy prorok, choć fizycznie umiera, zyskuje nieśmiertelność. Ostatnie wypowiadane przez niego z patosem słowa mają w sobie wiarę w moc człowieka:

Дети, братья, верю, верю в вас: плодитесь, растите, освещайте мир, устраивайте, осмысливайте его, познавайте, стройте, и вы будете как боги. Ведь боги, это - мечта о могуществе человеческом. Привет мой вам. [...] А вот мой новый дом, мое будущее: золотое, голубое, зовущее... Идем, идем! Смерти нет. Есть жизнь, такая огромная, о какой я не подозревал... 15

11 Jak twierdzi Józef Smaga, „Człowiek Maksyma Gorkiego nigdy nie był człowiekiem konkretnym, lecz abstrakcją złożoną z pobożnych życzeń i pobieżnych lektur”. J. Smaga, Maksym Gorki: koniec legendy, „Slavia Orientalis” 1993, nr 2, s. 245.

12 А. Луначарский, Русский Фауст, http://lunacharsky.newgod.su/lib/raznoe/russkij-faust [dostęp: 20.06.2015]; por. też wpis Łunaczarskiego do almanachu Kornieja Czukowskiego: „Bceчеловек - существо бессмертное, бесстрашное, окрыленное любовью”. К. Чуковский, Чукоккала. Рукописный альманах Корнея Чуковского, Москва 1979, s. 182.

13 Zob. Г. Ишимбаева, Русская фаустиана ХХ века. Учебное пособие, Москва 2002, rozdz. Фаустовская тема в контексте „веховской” проблематики (,„Фауст и Город” Анатолия Луначарского), s. 32-53.

14 А.В. Луначарский, Фауст и город, http://lunacharsky.newgod.su/lib/dramaticheskie-proizvedenia/faust-i-gorod [dostęp: 20.06.2015].

15 Ibidem. 
Faust jawi się tu jako wódz i artysta nieposkromiony i pełen pasji dążenia, by panować nad anarchistycznym żywiołem. Dramat Łunaczarskiego zapoczątkował pewien wzorzec interpretacyjny mitu faustowskiego, realizujący się w literaturze rosyjskiej lat dwudziestych i trzydziestych ubiegłego stulecia. Przynosi on odczytanie losu człowieka, jego dylematów etycznych oraz sensu ofiary w kontekście nowej porewolucyjnej epoki eksponującej aspekt transcendencji w wymiarze społeczno-ideologicznym. Ideologia rewolucyjna, ów świecki wariant religijnego mesjanizmu, wywodzi się z wiary w przeobrażenie świata i człowieka w oparciu $\mathrm{o}$ ideał piękna i harmonii.

Idea formowania człowieka reprezentującego postawę rewolucyjnej świętości, podporządkowanego energii kolektywu, przejawiającego potęgę woli i tworzenia zainteresowała liderów nowej władzy. Lew Trocki wielokrotnie wypowiadał się na temat ideologicznej ,przebudowy” społeczeństwa, szukając inspiracji we współczesnej nauce i psychologii ${ }^{16}$. Dotyczy to zwłaszcza bardzo popularnej w Rosji radzieckiej lat dwudziestych psychoanalizy Freuda. Trocki, zafascynowany Freudem, dostrzegał możliwości wykorzystania teorii wiedeńskiego psychiatry do stworzenia nowego ulepszonego gatunku homo sapiens dzięki wykorzystaniu technik służących do kontrolowania procesów psychicznych.

Koncepcje stworzenia nowej istoty ludzkiej owocują próbami połączenia psychoanalizy Freuda z marksizmem ${ }^{17}$, powstaniem i rozwojem pedologii ${ }^{18}$, psychotechniki, psychohigieny i refleksologii.

Faustowskie marzenia o nieśmiertelności i wiecznej młodości przybrały charakter eksperymentu społecznego, co potwierdzają doświadczenia nauko-

16 Por. wypowiedź Trockiego z 1923 r.: „Мы формируем конкретного человека нашей эпохи, который должен еще только бороться за создание условий, из которых вырастет гармонический гражданин коммуны”. Л. Троцкий, Задачи коммунистического воспитания, [w:] idem, Проблемы культуры. Культура переходного периода, http://bookz.ru/authors/ trockii-lev/problemi_613.html [dostęp: 20.06.2015]. Zdaniem Trockiego życie psychiczne człowieka nie może stać w sprzeczności z interesami klasowymi. O wyższości kolektywu nad jednostką pisał też Gorki w artykule pod znamiennym tytułem Разрушение личности. Zob. М. Горький, Очерки философии коллективизма, сб. 1, Санкт-Петербург 1909.

17 Już w 1904 r. przetłumaczono na język rosyjski dzieło Freuda O marzeniach sennych, kontynuatorami zaś metod terapeutycznych austriackiego psychiatry na gruncie rosyjskim byli tacy uczeni, jak Iwan Jermakow, Moisiej Wulf i Wiera Szmidt; w 1910 r. w Rosji ukazuje się pierwsze czasopismo psychiatryczne „Психотерапия. Обозрение вопросов психического лечения и прикладной психологии"; w latach dwudziestych XX wieku powstaje Rosyjskie Towarzystwo Psychoanalityczne, a także Psychoanalityczny Dom Dziecka, gdzie w oparciu o koncepcje Freuda prowadzone są eksperymentalne badania, których celem jest przygotowanie dzieci do pracy na rzecz kolektywu. Freud bardzo mocno wpłynął także na Lwa Wygotskiego, wybitnego rosyjskiego badacza zajmującego się psychologią twórczości, głoszącego tezę o biologicznym, społecznym i historycznym uwarunkowaniu psychiki człowieka. Wygotski był pierwszym uczonym rosyjskim, który podjął problem zależności między sztuką a psychoanalizą. Zob. L. Wygotski, Psychologia sztuki, tłum. M. Zagórska, Kraków 1980.

18 Zob. А. Залкинд, Педология. Утопия и реальность, Москва 2001. 
we uczonych radzieckich ${ }^{19}$ z lat trzydziestych ubiegłego wieku, prowadzące do stworzenia nowej istoty, faustowskiego homunkulusa o zdrowym ciele i stalowej woli ${ }^{20}$. Powstaje juwenologia, nauka o zachowaniu młodości i sposobach odmładzania organizmu, której celem miało być wyhodowanie nieśmiertelnego androgyna stanowiącego jedność społeczną, duchową i biologiczną. Ucieleśnieniem marzenia o nadczłowieku zdolnym zapanować nad przyrodą jest empiriomonizm, system filozoficzny, którego autorem jest Aleksandr Bogdanow. Nowy, panujący nad przyrodą człowiek, jak rozumował Bogdanow, narodzi się $\mathrm{w}$ procesie kolektywnego przekształcania świata.

Wobec najważniejszego hasła epoki porewolucyjnej, jakim był Nowy Człowiek, podporządkowany ideologii, nie pozostaje obojętna sztuka i literatura rosyjska. Wiara twórców zarówno w możliwość przeobrażenia świata, jak i w siłę ludzkiego ducha nieodłącznie związana była z pytaniem o sens eksperymentu społecznego, polegającego na wcieleniu w życie projektów Nikołaja Fiodorowa, Władimira Sołowjowa czy Maksyma Gorkiego, o odpowiedzialność moralną „nowych Faustów” za skutki owych działań.

Z takiej właśnie społeczno-ideologicznej perspektywy można interpretować powieści-alegorie Fatalne jaja (Роковые яйй, 1925) oraz Psie serce (Собачье сердие, 1926) Michaiła Bułhakowa. W utworach tych świat powstały wskutek eksperymentu okazuje się światem okaleczonym.

Każdy eksperyment naukowy, społeczny czy ideologiczny niesie bowiem w sobie niebezpieczeństwo nadużycia i destrukcji zastanego porządku moralnego, a ci, którzy obiecali „transmutację ołowiu w złoto, prometejski ogień wraz z magią Fausta, w gruncie rzeczy dokonują procesu odwrotnego, i mniemany

19 Zob. А. Куляпин, О. Скубач, Мифология советской повседневности в литературе и культуре сталинской эпохи, ред. И. Силантьев, Москва 2013, rozdz. Новое в физиологии мозга, s. 96-102 oraz М. Спивак, Посмертная диагностика гениальности, Москва 2001. W latach trzydziestych XX wieku prasa radziecka publikowała artykuły poświęcone badaniom prowadzonym w moskiewskim Instytucie Mózgu, które miały uzasadniać wykorzystanie radzieckich osiągnięć naukowych (szczególnie w dziedzinie neurofizjologii i neuropsychologii) w ideologicznym projekcie wyhodowania nowej istoty ludzkiej. Zob. М. Спивак, Тайна мозга Владимира Ленина, http://www.requiem.ru/news/2002/02/18/lenin/ [dostęp: 20.06.2015]. Badania nad społeczną przemianą człowieka w oparciu o założenia marksizmu prowadził Władimir Bechtieriew. Zdaniem twórcy refleksologii każdy akt świadomy człowieka ma podłoże materialne, a procesy społeczne wpływają na procesy psychiczne. Problemem uwarunkowań biologicznych i społecznych człowieka zajmował się neurobiolog Siergiej Briuchonienko, który wykorzystał wynaleziony przez siebie aparat sztucznego krwiobiegu do ożywiania organizmu psów w trakcie śmierci klinicznej; w latach trzydziestych z inicjatywy Gorkiego powstaje Wszechzwiązkowy Instytut Medycyny Eksperymentalnej pod kierownictwem Anatola Speranskiego; materialistyczna koncepcja Iwana Sieczenowa oparta na przekonaniu, że mózg jest narzędziem elektromechanicznym reagującym na bodźce zewnętrzne stała się podstawą badań podjętych przez Iwana Pawłowa na temat wyższych czynności nerwowych.

20 Prawzorem takiej niezłomności i hartu ducha był Rachmietow, bohater powieści Co robić? (Что делать?, 1862-1863) Nikołaja Czernyszewskiego. 
raj zamienia się w piekło" ${ }^{21}$. Takim właśnie „piekłem” jest państwo totalitarne z powieści Jewgienija Zamiatina $M y(M b l, 1920)$. Bunt w obronie wolności jednego z obywateli-numerów kończy się „Wielką operacją”, czyli wycięciem ośrodka wyobraźni z jego mózgu i tym samym pozbawienia go mocy sprawczej i woli sprzeciwu ${ }^{22}$. Zarówno Bułhakow, jak i Zamiatin demitologizują wartości kolektywne, występując w obronie autonomii jednostki i niezależności artysty.

W powieści Przywrócona młodość (Возвращенная молодость, 1933) Michaił Zoszczenko ponownie zadaje pytanie o etyczne skutki ówczesnych eksperymentów naukowych, dotyczących roli mózgu w pracy organizmu:

сейчас происходят любопытные опыты - у животного вырезают мозг, и тем не менее оно продолжает жить и живет месяцами. [...] В самом деле, а как живут эти животные, лишенные мозга? Оказывается, крыса с вырезанным полушарием мозга не имеет ни потребности есть, ни каких-либо других потребностей. Ее надо кормить, иначе она умрет через несколько дней. И полет бабочки лишен всякого смысла - она делает это механически ${ }^{23}$.

Ironiczną i groteskową modyfikacją motywu Fausta jest opowiadanie Lwa Łunca Pismo wychodzace $n r 37$ (Исходящая № 37. Дневник заведующего канцелярией, 1922). Bohater - biurokrata doskonały, ucieleśnienie absurdalnych reguł i paragrafów - marzy o całkowitym wyrugowaniu pierwiastka ludzkiego i zamianie wszystkich obywateli w papier. Siłą woli ten pospolity Faust przeistacza się $\mathrm{w}$ urzędowe pismo z przypisanym mu numerem:

Итак, великое свершилось, ибо я пишу эти строки в состоянии бумажного существования [...] Теперь не может быть никаких дискуссий, иными словами, прений по поводу моего изобретения. Я нахожусь в состоянии бумажного существования почти целые сутки и не испытываю ни голода, ни жажды, ни других потребностей... ${ }^{24}$

Bezkrytycznie przyjęte hasło „pieriekowki” człowieka okazuje się katastrofalne w skutkach dla bohatera, który nieświadomie staje się marionetką w rękach ideologów partyjnych, bezmyślną i całkowicie podporządkowaną władzy.

Faustowskie marzenie o pokonaniu czasu w nowej porewolucyjnej rzeczywistości realizuje się w przeciwstawieniu młodości, utożsamianej z entuzjastyczną wiarą $\mathrm{w}$ przeobrażenie świata ze starością, symbolizującą epokę moralności przedrewolucyjnej, skazaną na zapomnienie ${ }^{25}$. Motywy wiosny, zorzy, świtu, po-

${ }^{21}$ K. Dorosz, Faust wspótczesny, czyli De pacto hominis politici cum diabolo, Kraków 1984, s. 38 .

${ }^{22}$ Mniej więcej w tym samym czasie, kiedy Bułhakow i Zamiatin pracują nad swoimi utworami, które okazały się prorocze, zostaje przeprowadzona pierwsza operacja wycięcia mózgu u ptaków. Zob. А. Куляпин, О. Скубач, op. cit., s. 97.

23 М. Зощенко, Возвращенная молодость, Москва 2008, s. 204-205.

24 Л. Лунц, Исходящая № 37. Дневник заведующего канщелярией, http://az.lib.ru/l/ lunc_1_n/text_0030.shtml [dostęp: 20.06.2015].

${ }^{25}$ Przykładem wykorzystania motywu młodości przeciwstawiającej się starości jest film Dzigi Wiertowa Entuzjazm. Symfonia Donbasи (Энтузиазм. Симфония Донбасса, 1931). Obraz jest afirmacją rewolucyjnych przeobrażeń, których symbolem są młodzi, uśmiechnięci robotnicy 
ranka i młodości jako metafory przejścia do nowego świata pojawiają się w tytułach zbiorków wierszy poetów proletariackich lat dwudziestych: Zorza przyszłości (Заря будущего, 1920), Robotnicza wiosna (Рабочая весна, 1922), Świt (Paсcвет, $1921-1922)^{26}$.

W poemacie agitacyjnym Śmierć pionierki (Смерть пионерки, 1932) Eduarda Bagrickiego matka z krzyżem uosabia stary świat, śmierć młodej bohaterki jest natomiast symboliczną ofiarą rytualną złożoną rewolucji i znakiem podporządkowania się moralności nowych czasów ${ }^{27}$.

Tęsknotę za stanem młodości, odzwierciedlającą faustowską ideę nieśmiertelności, przejawia bohater liryczny wielu utworów Władimira Majakowskiego. W wierszach Jubileuszowe (Юбилейное, 1924) czy Komsomolskaja (Комсомольская, 1924) zbiorowy podmiot liryczny wygłasza płomienną tyradę na cześć zwycięskiej młodości, utożsamianej z rewolucyjnym odradzaniem się życia:

Ленин рядом.

Вот он.

Идет и умрет с нами.

И снова

в каждом рожденном рожден -

как сила,

как знанье,

как знамя ${ }^{28}$.

— tytani, stwarzający nowy świat. Ludzie starzy pojawiają się tylko na początku filmu, w scenie burzenia cerkwi, która oznacza radykalne odrzucenie przez nową władzę wartości chrześcijańskich poprzedniej epoki.

${ }^{26} \mathrm{~W}$ wierszu poety proletariackiego Aleksandra Biezymienskiego Młoda gwardia (Молодая гвардия, 1922), utrzymanym w tonacji patetycznej zwraca uwagę połączenie figury młodości z obrazem kolektywnego działania:

Вперед, заре навстречу,

Товарищи в борьбе!

Штыками и картечью

Проложим путь себе.

Смелей вперед, и тверже шаг,

И выше юношеский стяг!

Мы - молодая гвардия

Рабочих и крестьян.

Zob. А. Безыменский, Молодая гвардия, [w:] Z. Barański, J. Litwinow, Rosyjskie kierunki literackie. Przełom 19 i 20 wieku, Warszawa 1982, s. 363.

27 Niezwykle popularnym tematem była śmierć wodza rewolucji, interpretowana jako symbol ofiary, złożonej w imię lepszego świata. Motyw odradzania się idei leninowskiej pojawia się w radzieckich sloganach: „Ленин умер. Но Ленин жив в миллионах сердец”, „Умер Ленин, но дело его живет”, „Ильич жив в сердцах рабочих”, „Могила Ленина — колыбель человечества”, „Могила Ленина - колыбель мировой революции” itp.

${ }_{28}$ В. Маяковский, Комсомольская, [w:] idem, Избранные сочинения в двух томах, т. 1, Москва 1981, s. 176. 
Wyolbrzymione samotne „Ja” liryczne poematów Człowiek (Человек, 19161917) czy O tym (Про это, 1923), rzucając wyzwanie Bogu, samo kształtuje siebie na podobieństwo Boga-człowieka. Ta prometejska wizja człowieka — rewolucyjnego poety-tytana — była kreacją poety, próbą wyjścia poza swoją samotność i nadwrażliwość.

Motyw młodości, obecny także w twórczości Andrieja Płatonowa, związany jest $\mathrm{z}$ wiarą w przekształcenie świata i zbudowanie nowego, komunistycznego społeczeństwa. Powstanie owego raju na ziemi musi być jednakże okupione ofiarą. W powieściach Morze młodości (Ювенильное море, 1934) czy Wykop (Котлован, 1929-1930) faustowskie wyzwanie rzucone naturze i światu obraca się przeciwko człowiekowi, który, podporządkowując się ideologii, traci swoją tożsamość. Bohater powieści Władimira Zazubrina Drzazga. Opowieść o Niej i o Niej (Щепка. Повесть о Ней и о Ней, 1923), czekista i nieubłagany strażnik rewolucji, popełniane przez siebie zbrodnie usprawiedliwia wyższą koniecznością dziejową. Przekonany o własnej mocy, motywowany maksymalizmem etycznym ten funkcjonariusz partyjny przejawia również cechy natury faustowskiej ${ }^{29}$, zdolnej w imię abstrakcyjnego szczęścia do przekraczania wszelkich ograniczeń moralnych. O sowieckich niemoralnych i bezwzględnych Faustach pisał poeta Aleksander Wat:

Jeżeli zatem wspominam Fausta, to żeby wskazać, że bolszewikiem, i w ogóle totalistą, może być tylko natura faustowska, która dążąc niepohamowanie i za cenę potępienia wiecznego do celu, nie o cel dba, ale o drogę do niego właśnie niebezpieczną, i która w pryncypiach świadomości jest demonicznie czysta, tzn. skierowana wyłącznie ku szczęściu jako teoretycznie najwyższej wartości ${ }^{30}$.

Tęsknotę za młodością, utożsamianą ze zdrowiem i witalnością, przejawia wielu rosyjskich twórców urodzonych pod koniec XIX stulecia. Świat wartości, w których zostali wychowani, legł w gruzach, a ich poczucie przynależności do tradycji zostało zachwiane.

Pełen nadziei i wiary jest Osip Mandelsztam: „Еще не знаю, что с собой делать. Как будто еще очень молод. »Общественный ремонт здоровья« значит, от меня чего-то доброго ждут, верят в меня" 31 . Przeświadczenie o własnym poetyckim posłannictwie jest $\mathrm{u}$ Mandelsztama nieodłączne z głębokim pragnieniem bycia częścią wspólnoty: „Я должен жить, дыша и большевея”32. Bardzo podobne myślenie przejawia Konstantin Waginow, nazywając ludzi od-

29 Zob. B. Waligórska-Olejniczak, Zmysty jako dekoder rzeczywistości. „Drzazga” Władimira Zazubrina i malarstwo René Magritte'a, [w:] Wielkie tematy kultury w literaturach stowiańskich. Zmysty, red. I. Malej, E. Tyszkowska-Kasprzak, Wrocław 2014, s. 256.

30 A. Wat, Świat na haku i pod kluczem, Warszawa 1991, s. 222.

31 Słowa te wypowiedział Mandelsztam w 1938 r. przed swoim powtórnym aresztowaniem. Zob. Б. Сарнов, Последний творческий акт. Случай Мандельштама, Москва 2000, s. 29.

32 O. Мандельштам, Cmaнсы, [w:] O. Mandelsztam, Poezje, wybór, red., posłowie M. Leśniewska, Kraków-Wrocław 1983, s. 422. 
chodzącej w przeszłość epoki „eksponatami muzealnymi” "33, Jurij Olesza zaś konstatuje: „Я интеллигент [...] - наследник культуры, которой дышит весь мир и которую строители нового мира считают обреченной на гибель" 34 .

Uczuciu upokorzenia i zawiści wobec pokolenia, które pozbawione dylematów moralnych buduje nową rzeczywistość, towarzyszy wiara i nadzieja na przywrócenie młodości. Bohater opowiadania Oleszy Mój znajomy (Мой знакомыій, 1929) zwierza się:

Nie mam przeszłości. Rewolucja dała mi zamiast niej rozum. Pozbyłem się miałkich uczuć, jestem absolutnie samodzielny. Jeszcze się ogolę, wystroję. Jeszcze będę rozkoszować się życiem. Rewolucja zwróci mi młodośćc 35 .

Protagonista opowiadania Materiat ludzki (Человеческий материал, 1928) wierzy, że można odrzucić przeszłość i odrodzić się duchowo:

Pragnę zdławić w sobie moje drugie „ja” i trzecie, i wszystkie „ja”, które wypełzają z przeszłości. Chcę zniszczyć w sobie miałkie uczucia ${ }^{36}$.

Tęsknotę twórców rosyjskich za wieczną młodością, za przekroczeniem ograniczeń czasowo-przestrzennych i osiągnięciem szczęścia na ziemi można interpretować jako próbę ucieczki przed samotnością i odrzuceniem społecznym w warunkach presji ideologicznej. Mit zdrowia i wiecznej młodości jest jednak przede wszystkim wyrazem odwiecznego lęku człowieka przed starością i śmiercią. Taki egzystencjalny lęk przeżywa profesor Wasilij Wołosatow, bohater powieści Michaiła Zoszczenki Przywrócona młodość (Возвращенная молодость, 1933), którą nazwać można radzieckim wariantem Fausta Goethego ${ }^{37}$. Starość postrzegana jest przez uczonego astronoma, alter ego Zoszczenki, jako przywiązanie do przeszłości, nienadążanie za rytmem nowej epoki, natomiast marzenia o powrocie do stanu beztroskiej młodości są przejawem tęsknoty za roztopieniem się w kolektywie. Wołosatow, na podobieństwo Fausta Goethego, u kresu swojego życia przeżywa dramat; przekonuje się bowiem, że jego wiara w rozum była błędem, nie osiągnął on poznania i nie doświadczył życia w pełni. Chce więc zatrzymać czas, młodość i miłość, a gwarantem przywrócenia jego zdrowia fizycznego i psychicznego ma być zaangażowanie się w działalność społeczną.

33 А. Блюмбаум, Оживающая статуя и воплощенная музыка. „Контексты Старого юноши”, „Новое литературное обозрение” 2008, nr 89, http://www.nlobooks.ru/rus/magazines/ nlo/196/789/ [dostęp: 30.06.2015].

34 Ю. Олеша, Зависть. Ни дня без строчки. Рассказы. Статьи, Москва 1999, s. 7.

35 J. Olesza, Mój znajomy, [w:] idem, Pestka wiśni. Wybór prozy, tłum. A. Galis, Kraków 1984, s. 74-75.

36 J. Olesza, Materiał ludzki, [w:] idem, Pestka wiśni..., s. 67.

37 Władimir Fiodorow sugeruje, że tytuł powieści mógł Zoszczenko zaczerpnąć od niemieckiego poety. Zob. B.С. Федоров, Об онтологических и философских аспектах мировоззрения Зощенко, [w:] Михаил Зощенко. Материаль к творческой биографии, т. 1, ред. Н. Грознова, Санкт-Петербург 1997; oraz A. Kotkiewicz, Nowy czlowiek Michaiła Zoszczenki. Trylogia: „Przywrócona młodośc”,, „Niebieska księga”, „Przed wschodem słońca”, Kraków 2012. 
Walka pomiędzy chęcią niezależności i koniecznością dostosowania się do realiów życia jest podstawowym dylematem Wołosatowa. Przywrócenie młodości, utożsamiane ze zdrowiem i równowagą wewnętrzną, nie zmienia samej rzeczywistości, lecz jej obraz w umyśle człowieka. Po raz kolejny wątek starości i młodości, choroby i zdrowia, niezwykle ważny dla Zoszczenki, pojawi się w jego ostatniej powieści Przed wschodem słońca (Перед восходом солнца, 1943). Jest to próba połączenia nauki Iwana Pawłowa o odruchach warunkowych z psychoanalizą Freuda. Podejmując polemikę z oficjalnie propagowaną wizją człowieka radzieckiego i występując w obronie ludzkiej podmiotowości, pisarz eksponuje obraz istoty doskonałej, wolnej, rozumnej, posiadającej kontrolę nad swoim ciałem i psychiką.

Na kilka miesięcy przed śmiercią w liście do Kornieja Czukowskiego Zoszczenko napisał:

Рецептура, впрочем, и у меня есть. Надо игнорировать старость. И тогда тело будет послушно выполнять предначертанное. Пожалуй, не только старость, но и смерть зависит от собственного мужества ${ }^{38}$.

Polemiką z faustowskim motywem demiurga, herosa, który pragnie dokonać transformacji świata, jest powieść Doktor Żywago (Доктор Живаго, 1948-1955) Borysa Pasternaka, nad którą pisarz pracował od lat dwudziestych ubiegłego wieku. Wartość najwyższą zdaniem głównego bohatera — przedrewolucyjnego inteligenta, lekarza i poety — stanowi życie. Nie jest ono jednak, twierdzi Żywago, materiałem, który można poddawać obróbce ideologicznej. Najważniejsza jest akceptacja rzeczywistości w jej trwaniu, płynności, wiecznym odnawianiu się. Bohater czerpie swoją siłę z poczucia wewnętrznej wolności tworzenia, miłości i ładu moralnego. Faust Pasternaka nie jest społecznikiem i burzycielem zastanej rzeczywistości, on się godzi na rzeczywistość i nie pragnie jej rewolucyjnie przeobrażać.

Problematyka egzystencjalna, akcentowanie wolności twórczej i przestroga przed realizacją utopii społecznej drogą rewolucyjnej przemocy są też obecne w powieści Mistrz i Matgorzata (Macmep u Mapzapuma, 1928-1940) Michaiła Bułhakowa. Reinterpretując podjęty przez Goethego wątek poznania dobra i zła, sfery sacrum, wiary, miłości, granic wolności człowieka, Bułhakow nawiązuje do metafizycznej warstwy Fausta Goethego, dotyka także problemu wolności twórczej i tyranii w rzeczywistości stalinowskiej. Przewodnikiem po świecie zła jest Woland-Faust. Wielki mag nie chce zmieniać człowieka, akceptuje go ze wszystkimi jego wadami. Ukazanie prawdziwej natury ludzkiej jest $\mathrm{w}$ istocie zaaprobowaniem istoty wszechświata, w której równoważą się dobro i zło, a najważniejsza staje się odwieczna tęsknota człowieka za wolnością.

Postać Fausta, niejednoznaczna i niezwykle nośna tematycznie, w literaturze rosyjskiej lat dwudziestych i trzydziestych XX wieku związana jest z próbą urzeczywistnienia prometejskiego mitu kreacji. Przynosi ona różne interpretacje artystyczne: od zachwytu nad Człowiekobogiem, rewolucjonistą i społeczni-

${ }^{38}$ Maszynopis listu M. Zoszczenki do K. Czukowskiego z dn. 11.02.1958 r. dostępny w Archiwum Michaiła Zoszczenki, Muzeum Literatury „XX wiek”, Sankt Petersburg. 
kiem, do jego zdemaskowania jako bezwzględnego realizatora utopii społecznej. Odczytywany w perspektywie uniwersalnej motyw Fausta zawsze jednak pozostanie wyrazem światopoglądowych i etycznych rozterek człowieka oraz jego marzenia o nieśmiertelności.

\section{Bibliografia}

Dorosz K., Faust współczesny, czyli De pacto hominis politici cum diabolo, Kraków 1984.

Goethe W., Faust, tłum. J. Paszkowski, Kraków 2002.

Kotkiewicz A., Nowy człowiek Michaiła Zoszczenki. Trylogia: „Przywrócona młodośc”, „Niebieska księga”, „Przed wschodem słońca”, Kraków 2012.

Mandelsztam O., Poezje, wybór, red., posłowie M. Leśniewska, Kraków-Wrocław 1983.

Maszynopis listu M. Zoszczenki do K. Czukowskiego z dn. 11.02.1958 r. dostępny w Archiwum Michaiła Zoszczenki, Muzeum Literatury „XX wiek”, Sankt Petersburg.

Olesza J., Pestka wiśni. Wybór prozy, tłum. A. Galis, Kraków 1984.

Smaga J., Maksym Gorki: koniec legendy, „Slavia Orientalis” 1993, nr 2.

Waligórska-Olejniczak B., Zmysty jako dekoder rzeczywistości. „Drzazga” Władimira Zazubrina i malarstwo René Magritte'a, [w:] Wielkie tematy kultury w literaturach słowiańskich. Zmysty, red. I. Malej, E. Tyszkowska-Kasprzak, Wrocław 2014.

Wat A., Świat na haku i pod kluczem, Warszawa 1991.

Wygotski L., Psychologia sztuki, tłum. M. Zagórska, Kraków 2001.

Блюмбаум А., Оживающзая статуя и воплощенная музыка. Контексть „Старого юноши”, „Новое литературное обозрение” 2008, nr 89.

Горький М., Очерки философии коллективизма, сб. 1, Санкт-Петербург 1909.

Залкинд А., Педология. Утопия и реальность, Москва 2001.

Зощенко М., Возвращенная молодость, Москва 2008.

Ишимбаева Г., Русская фаустиана ХХ века. Учебное пособие, Москва 2002.

Куляпин А., Скубач О., Мифология советской повседневности в литературе и культуре сталинской эпохи, ред. И. Силантьев, Москва 2013.

Луначарский А., Русский Фауст, http://unacharsky.newgod.su/lib/raznoe/russkij-faust.

Луначарский А., Фауст и Город, http://unacharsky.newgod.su/lib/dramaticheskie-proizvedenia/faust-i-gorod.

Лунц Л., Исходящ̧ая № 37. Дневник заведующчего канщеелярией, http://az.lib.ru/1/lunc_1_n/ text_0030.shtml.

Маяковский В., Избранные сочинения в двух томах, т. 1, Москва 1981.

Олеша Ю., Зависть. Ни дня без строчки. Рассказыл. Статьи, Москва 1999.

Сарнов Б., Последний творческий акт. Случай Мандельштама, Москва 2000.

Спивак М., Посмертная диагностика гениальности, Москва 2001.

Спивак М., Тайна мозга Владимира Ленина, http://www.requiem.ru/news/2002/02/18/lenin.

Троцкий Л., Проблемы культуры. Культура переходного периода, http://bookz.ru/authors/ trockii-lev/problemi_613.html.

Федоров В., Об онтологических и философских аспектах мировоззрения Зощенко, [w:] Михаил Зощенко. Материалы к творческой биографии, т. 1, ред. Н. Грознова, СанктПетербург 1997.

Флакер А., Предпосылки социалистического реализма, „Вопросы литературы” 1992, nr 1. Чуковский К., Чукоккала. Рукописный альманах Корнея Чуковского, Москва 1979.

Эткинд А., Эрос невозможного. История психоанализа в России, Санкт-Петербург 1993. 


\section{"Ah, linger on, thou art so fair!": The faustian motif in the Russian literature of the 1920s-1930s}

\section{Summary}

The faustian motif is one of the most important themes of European literature. The 16th-century German alchemist and magician is a symbol of a free and independent human being, obsessed by the idea of transgressing all the boundaries in order to gain absolute knowledge. Highly ambiguous and semantically loaded, the Faustian figure also appears in the works of many Russian writers, such as Vasily Zhukovsky, Alexander Pushkin, Valery Bryusov and Leonid Andreyev; it is also present in the theory of God-Building propounded by Maxim Gorky and Anatoly Lunacharsky. In his play Faust and the City, Lunacharsky proposed an interpretative paradigm of the faustian myth that was implemented in the Russian literature of the 1920s-1930s. This paradigm offered a reading of Faustian dilemmas in the context of a new post-revolutionary epoch, emphasizing the socio-ideological dimension of the aspect of transcendence. The reinterpretation of the German writer's theme of perennial youth, good and evil, and the limits of human freedom found its artistic reflection in the works of such outstanding writers of the 1920-1930s as Mikhail Bulgakov, Yury Olesha, Yevgeny Zamyatin, Mikhail Zoshchenko, Daniil Kharms, Vladimir Mayakovsky and Osip Mandelstam.Yearning for eternal youth, for transgressing temporal and spatial borders and achieving happiness in earthly life testifies to humans' fear of old age and death. In the works of the Russian writers mentioned above the faustian motif can be understood not only as an expression of moral and ideological dilemmas but first and foremost as an attempt to escape from loneliness and social alienation in the situation of ideological pressure.

Keywords: the faustian motif, transcendence, ideology, youth, old age

\section{„Остановись, мгновенье, - ты прекрасно!” Фаустовский мотив в русской литературе 20-х и 30-х годов ХХ века}

Резюме

Фауст - это метафора свободного и независимого существа, одержимого идеей перешагнуть всевозможные границы с целью достижения абсолютного познания. Фаустовский мотив - один из важнейших в европейской литературе, также появляется в творчестве русских писателей: Василия Жуковского, Александра Пушкина, Валерия Брюсова, Леонида Андреева. Можно его также обнаружить в философии богостроительства Максима Горького и Анатолия Луначарского. В своей драме Фауст и город Луначарский дал образец интерпретации фаустовского мотива, который появляется затем в русской литературе 20 -х и 30 -х годов XX века. Он рассматривается нами в контексте новой послереволюционной эпохи, для которой трансцендентность приобретает социально-идеологическое толкование. Реинтерпретация предпринятой Гете темы вечной молодости, познания добра и зла, границ человеческой свободы, нашла художественное воплощение в творчестве Михаила Булгакова, Юрия Олеши, Евгения Замятина, Михаиля Зощенко, Владимира Маяковского, Осипа Мандельштама. Тоска по вечной молодости и достижению счастья на земле олицетворяет 
извечный страх человека перед старостью и смертью. Фаустовский мотив можно толковать как выражение этических и мировоззренческих дилемм вышеупомянутых писателей, но прежде всего как попытку бегства от одиночества в условиях идеологического давления.

Ключевые слова: Фауст, трансцендентность, идеология, молодость, старость 